\title{
MELUKISKAN AKUNTANSI DENGAN KUAS INTERPRETIF
}

\author{
Nurhayati \\ Dosen Universitas Dr Soetomo Surabaya
}

\begin{abstract}
This study departs from the domination of accounting studies using the paradigm of positivistic methodology. The aim in this study provides an alternative approach in developing interpretive accounting research. Triyuwono (2013) says there are five paradigms in the social sciences: positivism, interpretivism, criticism postmodernism, and spiritualists. Interpretivis paradigm, critical, postmodernist and spiritualists using qualitative methods, which is the development of positivistic paradigm. This paradigm is not mutually exclusive, ideally an accounting researchers must be able to accept this paradigm, called "multiparadigma" (Triyuwono, 2013). Interpretive considers that truth, reality or real life does not have a one-sided, but it has many facets, can be examined from various viewpoints. Design research in interpretive research, phenomenology, ethnography, ethnometodology, narrative, case studies, and grounded theory.
\end{abstract}

Key words: paradigm, accounting, interpretive

\section{A. Pendahuluan}

Para ilmuwan sosial seringkali dihadapkan dengan pertanyaan ontologis dasar: apakah realitas diteliti sebagai suatu yang berada di luar diri manusia yang merasuk ke dalam alam kesadaran seseorang; ataukah merupakan hasil dari kesadaran seseorang? Apakah realitas itu merupakan keadaan yang obyektif atau hasil dari pengetahuan seseorang (subyektif)? Apakah realitas itu memang sesuatu yang sudah ada (given) di luar pikiran seseorang atau hasil dari pikiran seseorang.

Muncullah paham nominalisme yang merupakan aliran teologis yang berusaha melawan dan mereduksi paham-paham yang bersifat universal baik dalam alam pikiran maupun dalam dunia benda-benda(Kristiyanto, 2004:27). Sementara itu, 
munculnya paham ini juga dilatarbelakangi oleh pandangan yang ingin menggeneralisasikan apa saja. Selanjutnya, paham nominalisme berkembang pada Abad Pertengahan dengan mengajarkan bahwa nama-nama benda, meskipun berguna untuk membuat klasifikasi, sebenarnya tidak dapat menggambarkan realitas. Setiap substansi dirasakan bersifat individual dan tidak ada kodrat yang umum (O'Collins, 1996:216).

Realisme di sisi lain, berpatokan bahwa dunia sosial eksternal untuk kesadaran individual merupakan dunia nyata yang tercipta dari sesuatu yang keras, nyata, dan relative tidak berubah. Realisme beranggapan bahwa realita sosial sebagai sesuatu di luar diri seseorang, merupakan kenyataan yang berwujud, dapat diserap, dan merupakan tatanan nisbi yang tetap.

Menurut Burrell dan Morgan, dalam ilmu sosial, seorang nominalis beranggapan bahwa "dunia sosial yang berada diluar kognisi individu tidak lebih tersusun dari sekedar nama, konsep dan label yang digunakan untuk menstrukturkan realitas" dan digunakan " sebagai kreasi artifisial yang kegunaannya didasarkan pada kemudahan untuk menggambarkan, mengartikan, dan menegosiasikan dunia eksternal" (Burrell dan Morgan1979:4). Bagi kaum realis, realitas sosial independen dari aktor-aktor sosial dam mengada sendiri, bukan sesuatu yang diciptakan individu (Burrell dan Morgan1979:4).

Dari kedua paham tersebut, timbullah keinginan bahwa harus dicari suatu paradigma yang dapat menjawab semua pertanyaan-pertanyaan tentang dunia sosial. Mau tidak mau kita harus membangun paradigma baru dalam memahami dunia secara keseluruhan. Sebuah pandangan-dunia yang melihat sesuatu dengan cara-pandang penuh totalitas, organis, ekologis dan holistik serta integral (paradigma holistik. Pandangandunia holistik tidak melihat manusia dan lingkungannya sebagai entitas terpisah yang tidak memengaruhi satu sama lain.

\section{B. Pembahasan}

Manusia melihat lingkungannya tidak sebatas objek yang terpisah sama sekali terhadap dirinya, melainkan entitas yang saling memengaruhi satu sama lain serta menganggap sebagai 
pengalaman yang terkait dengan hidupnya. Dengan demikian lingkungan dilihat sebagai entitas bermakna, berkehidupan dan berkesadaran. Begitu juga dalam ranah sosial. Manusia tidak melihat sesamanya sebagai objek dan melihat pengalaman sesamanya sebagai pengalaman yang berkaitan dengannya, serta saling memengaruhi satu sama lain, dengan kata lain tidak terpisah sama sekali.

Dari pemahaman di atas, mulailah dicari pradigmaparadigma baru untuk menjawab pertanyaan-pertanyaan yang tidak dapat terjawab oleh paradigma positivistik. Dalam ranah penelitian-penelitian ilmu sosial(termasuk riset akuntansi) yang dimensinya meliputi obyektifisme dan subyektifisme, Burrel Morgan $(1979,22)$ mengklasifikasikan ada empat paradigma utama yaitu fungsionalisme, interpretifisme, radikal humanisme, dan radikal strukturalisme. Triyuwono $(2012 ; 236)$ dalam literaur yang lain menyebutkanempat paradigmadalam ilmu sosial, yaitu positivisme, interpretivisme, kritisisme dan posmodernisme.Dalam paradigma ini muncullah kesadaran akan self and the other, Triyuwono (2007) menyatakan bahwa keberadaan manusia tidak bisa terlepaskan dari prinsip religiusitas Manunggaling Kawulo-Gusti dari Syeikh Siti Jenar:

"kemanunggalan" (unity) atas dua hal atau lebih yang berbeda. Misalnya kemanunggalan manusia (sebagai mahluk) dengan Tuhan (sebagai Sang Pencipta), kemanunggalan suka dengan duka, kemanunggalan benar dengan salah, dan lain-lainnya. [Dua] hal yang berbeda tersebut tidak saling meniadakan (mutually exclusive), tetapi sebaliknya saling menyatu [mutually inclusive].

Paradigma interpretivis, kritis, postmodernis dan spiritualis menggunakan metode kualitatif, yang merupakan pengembangan dari paradigma positivistik, dan sampai sekarang paradigma-paradigma tersebut masih eksis. Paradigam ini tidak bisa saling meniadakan, dan secara ideal seorang peneliti akuntansi harus dapat menerima paradigma tersebut, yang biasanya disebut dengan "multiparadigma" (Triyuwono, 2013). Selanjutnya (Triyuwono, 2013) menjelaskannya dalam bentuk tabel

di

bawah

ini: 


\section{Tabel 1}

Tujuan dan Bentuk Ilmu dari Masing-masing Paradigma

\begin{tabular}{|l|l|l|l|l|}
\hline No & Paradigma & $\begin{array}{l}\text { Tujuan } \\
\text { Penelitian }\end{array}$ & $\begin{array}{l}\text { Bentuk Ilmu } \\
\text { Pengetahuan }\end{array}$ & $\begin{array}{l}\text { Area } \\
\text { Akuntansi }\end{array}$ \\
\hline 1 & Positivis & $\begin{array}{l}\text { Menjelaskan (to } \\
\text { explain) dan } \\
\text { meramalkan (to } \\
\text { predict }\end{array}$ & $\begin{array}{l}\text { Bersifat deduktif } \\
\text { berdasarkan } \\
\text { pada panca } \\
\text { indra, prosedur } \\
\text { ketat, nomotetis, } \\
\text { bebas nilai }\end{array}$ & $\begin{array}{l}\text { Corporate } \\
\text { accounting dan } \\
\text { non-corporate } \\
\text { accounting }\end{array}$ \\
\hline 2 & Interpretivis & $\begin{array}{l}\text { Menafsirkan (to } \\
\text { interpret)dan } \\
\text { memahami } \\
\text { understand })\end{array}$ & $\begin{array}{l}\text { Bersifat induktif } \\
\text { berdasarkan } \\
\text { pada } \\
\text { interpretasi, } \\
\text { ideografis, } \\
\text { akal sehat, dan } \\
\text { sarat nilai }\end{array}$ & $\begin{array}{l}\text { Corporate } \\
\text { accounting dan } \\
\text { non-corporate } \\
\text { accounting }\end{array}$ \\
\hline 3 & Kritis, & $\begin{array}{l}\text { Membebaskan } \\
\text { (to emancipate) } \\
\text { dan mengubah } \\
\text { (to transform) }\end{array}$ & $\begin{array}{l}\text { Bersifat konkrit } \\
\text { berdasarkan } \\
\text { padainterpretasi, } \\
\text { membebaskan } \\
\text { dan merubah, } \\
\text { serta sarat nilai }\end{array}$ & $\begin{array}{l}\text { Corporate } \\
\text { accounting dan } \\
\text { non-corporate } \\
\text { accounting }\end{array}$ \\
\hline 4 & Postmodernis & $\begin{array}{l}\text { Mendekons- } \\
\text { truksi (to } \\
\text { deconstruct) }\end{array}$ & $\begin{array}{l}\text { Bersifat kompleks } \\
\text { dan } \\
\text { majemuk, serta } \\
\text { sarat nilai }\end{array}$ & $\begin{array}{l}\text { Corporate } \\
\text { accounting dan } \\
\text { non-corporate } \\
\text { accounting }\end{array}$ \\
\hline 5 & Spiritualis & $\begin{array}{l}\text { Membangkitkan } \\
\text { kesadaran } \\
\text { keTuhanan (to } \\
\text { awakened God } \\
\text { Conciousness) }\end{array}$ & $\begin{array}{l}\text { Bersifat } \\
\text { transendental, } \\
\text { utuh, dan sarat } \\
\text { nilai }\end{array}$ & $\begin{array}{l}\text { Corporate } \\
\text { accounting dan } \\
\text { non-corporate } \\
\text { accounting }\end{array}$ \\
\hline
\end{tabular}

Sumber: Dikutip dari Triyuwono (2013)

\section{Paradigma Interpretif dan Perkembangan Ilmu Pengetahuan Sosial}

Interpretif berasal dari tradisi ilmu sosial, khususnya sosiologi dan antropologi, yang diawali oleh kelompok ahli sosiologi dari "mazhab Chicago" pada tahun 1920-1930. Pada tahun 1960 di Amerika dan pada 1970-an di negara-negara berbahasa Jerman, paradigma interpretif mengalami kebangkitan.

Sejak saat itu, paradigma ini berkembang pesat, khususnya dalam ilmu sosial dan humaniora. Dunia dipandang sebagai sesuatu yang tidak tertata dan terpola secara obyektif, sehingga diperlukan pendekatan khusus untuk memahami setiap gejala yang muncul. Tidak seperti paradigma positivistik 


\section{Nurhayati}

yang dimulai dari teori/hipotesis, paradigma interpretif dimulai dari suatu fenomena yang selanjutnya didalami untuk menghasilkan teori

Tujuannya ialah untuk memahami makna atas pengalaman seseorang atau sekelompok orang dalam suatu peristiwa. Pengalaman bukan kenyataan empirik yang bersifat obyektif, melainkan pelajaran yang bisa dipetik dari peristiwa yang dilalui seseorang.

Kebenaran diperoleh lewat pemahaman secara holistik, dan tidak semata tergantung pada data atau informasi yang teramati, melainkan pula mendasarkan pada informasi yang tidak tampak dan digali secara rinci. Akal sehat (common sense) bisa menjadi landasan mencari kebenaran. Kebenaran bersifat unik, dan tidak bisa berlaku secara umum dan diperoleh lewat proses induktif. Penelitian interpretif ini bersifat valuebound, sehingga peneliti terlibat secara aktif bersama subyek untuk memperoleh kebenaran

Behling (1980) mengungkapkan bahwa ilmu metode natural science sudah gagal dalam menjelaskan perilaku organisasi dan teori organisasi, karena 2 alasan: yaitu bahwa pertama karena metode natural science secara tipikal hanya mempertanyakan satu sisi pertanyaan, dan kedua karena metode natural science hanya mempertimbangkan satu atau dua isu penting dari kegunaan pendekatan natural science dalam penelitian.

Selanjutnya Behling (1980) menjelaskan ada 5 hal mengapa paradigma interpretif lebih cocok digunakan dalam mengungkapkan fenomena perilaku manusia dalam ilmu sosial, dikarenakan ada 5 hal:

1. Keunikan.

Bahwa tiap organisasi, grup, dan manusia berbeda satu sama lainnya, sehingga perbedaan karakter manusia yang menyajikan, memakai produk-produk akuntansi juga akan berbeda pula dapat diinterpretasikan dalam riset akuntansi juga.

2. Kestabilan.

Fenomena menarik bagi peneliti dalam perilaku organisasi bersifat sementara. Tidak hanya mengungkapkan "fakta" 
dari perubahan kejadian sosial berdasarkan waktu, tetapi juga mengapa hal itu terjadi.

\section{Sensitivitas.}

Tidak seperti dalam pendekatan positivistik, orang-orang dalam organisasi dan organisasi itu sendiri sadar sepenuhnya bahwa mereka sedang di"hipotesis"kan.

4. Kurangnya realisme.

Memanipulasi dan mengontrol variabel dalam melaksanakan riset merubah fenomena riset itu sendiri. Sehingga riset seharusnya tidak dapat digeneralisasikan karena fenomena yang diteliti akhirnya berbeda dengan pasangannya dalam "dunia nyata".

5. Perbedaan epistimologi.

Meskipun hukum sebab akibat merupakan hal yang sangat dipertanyakan dalam mengungkapkan fenomena, tetapi "ilmu pengetahuan" yang lain tidak dipergunakan dalam mengungkapkan fenomena tersebut.

Paradigma interpretif merupakan paradigma yang memandang bahwa kebenaran, realitas atau kehidupan nyata tidak memiliki satu sisi, tetapi dapat memiliki banyak sisi, sehingga dapat dikaji dari berbagai sudut pandang. Sehingga tingkat subyektifitas dari paradigma interpretif sangatlah tinggi. Paradigma ini menolak adanya anggapan bahwa kebenaran atau pengetahuan yang telah ada harus selalu diverifikasi, sehingga kelak suatu kebenaran yang tunggal dapat tercapai dan terbangun. Paradigma ini memandang bahwa realita dunia ini terdiri dari banyak kebenaran yang saling terkait. Untuk mengungkapkan kebenaran-kebenaran tersebut dan keterkaitannya, manusia harus memiliki kemampuan untuk menginterpretasikan atau menafsirkan setiap fenomena yang dapat ditangkap oleh inderawinya.

Paradigma interpretif apabila penelitinya memandang obyek yang ditelitinya memiliki keunikan tersendiri dan mengandung kebenaran yang orisinil, sehingga memposisikannya sebagai fenomena yang ditelitinya sebagai 'fenomena'. Keunikan 


\section{Nurhayati}

tersebut seringkali muncul karena keterikatan obyek tersebut terhadap konteks lingkungannya, seperti terhadap ruang dan waktu terjadinya fenomena tersebut, sehingga dipandang tidak atau jarang terjadi dan terdapat di tempat dan waktu yang lain. Hal ini menyebabkan metoda yang dipergunakan di dalam penelitian fenomena yang demikian, pada umumnya bersifat alamiah, karena sangat terikat pada konteks yang sebenarnya. Akibatnya, kebenaran atau pengetahuan yang dihasilkan dari penelitian yang demikian pada umumnya bersifat lokalitas dan kontekstual, dan tidak bermaksud unutk mengeneralisasikan temuan penelitian.

\section{Melukiskan Akuntansi dengan Kuas Paradigma Interpretif}

Knuuttila,MLK,dkk,(2008)melaluirisetnyamembuktikan bahwa dengan paradigma interpretif dapat menganalisis dan menyediakan alat konseptual untuk mengartikulasikan dengan lebih presisi apa yang ditegaskan dalam sebuah fenomena akuntansi manajemen yang tidak dapat dilakukan oleh paradigma positivistik karena mempunyai argumen filosofis yang abstrak dan umum yang sering digunakan hanya untuk masalah kasus awam yang lebih relevan specifik mengenai fokus penjelasan dan sifat bukti empiris yang ditawarkan.

Knuuttila,MLK, et al, (2008) juga menyatakan bahwa penelitian interpretif, selain termasuk elemen subyektif, juga mencakup objektivis fitur, bertujuan menyediakan alat konseptual untuk mengartikulasikan dengan lebih presisi apa yang ditegaskan dalam sebuah studi yang diberikan. Interpretasi bertujuan memahami makna, dan kausalitas, dapat berhasil hidup berdampingan dan bekerja sama dalam satu studi tunggal.

Dalam penelitian interpretif, teori yang akan digunakan untuk memahami data sangat mungkin berubah. Waktu ke lapangan, bisa jadi kita mempunyai teori yang kita bayangkan akan kita gunakan dalam analisis. Tetapi, sangat mungkin ketika di lapangan, data yang dapat dikumpulkan tidak sesuai dengan yang kita harapkan. Arah penelitian kita bisa berubah, dan ini tidak masalah dalam penelitian interpretif. Interview guide hanya sebuah panduan. Kita bisa (kalau menurut saya, bahkan harus) berimprovisasi di lapangan untuk memahami sebuah fenomena dengan lebih baik. Biarkan wawancara berjalan dengan cair. 
sangat mungkin, ada banyak informasi yang menurut kacamata awal kita (karena dibatasi teori) tidak relevan. Tetapi di sinilah seninya. Ketika sampai dalam tahap analisis data, seringkali 'muncul' alur cerita yang lebih menarik yang tidak pernah kita bayangkan, dan data yang tadinya kita anggap tidak relevan menjadi sangat bermanfaat.

Teori pun kadang tidak serta merta menyediakan kosa kata untuk menjelaskan fenomena ini. Kita perlu mengusung teori baru, atau bahkan beberapa teori baru yang tidak pernah kita rencanakan sebelumnya.Mengapa demikian? Karena dalam penelitian interpretif, semua fenomena dianggap sebagai hasil sebuah konstruksi sosial. banyak hal dan pihak yang terlibat di sana. Praktik ini akan lebih menarik lagi kalau dikaitkan dengan grounded research. Artifak wawancara (transkrip, rekaman), termasuk catatan/diari kunjungan lapangan, adalah datanya. Berdasar data ini, kita bisa membuat cerita yang menghubungkan kejadian, konsep, aktor atau apa saja yang ditemukan di sana. Untuk memahami cerita tersebut lebih jauh, kita bisa menggunakan teori yang tepat. Teori ini bahkan kadang tidak pernah kita pelajari dan pikirkan sebelumnya ketika sedang dalam tahap pengumpulan data. Dalam penelitian interpretif, data yang sudah kita kumpulkan masih relevan dan bermanfaat. Yang diperlukan adalah mencari teori yang tepat untuk menjelaskan fenomena.

Metode interpretif ini dianggap sebagai suatu metode yang dapat digunakan dalam sains kultural untuk menghasilkan suatu pengetahuan dengan obyektifitas yang dapat dibandingkan dimana pengetahuan yang dipelajari adalah dengan mengaitkan pemgalaman beberapa orang untuk memahami dunia. Dengan demikian filosofi sosial memiliki pengaruh tak langsung pada berbagai unsur yang merupakan karakteristik paradigma interpretif untuk menjelaskan akuntansi sebagai ilmu sosial.

Sofyan (1997:37) menyatakan bahwa akuntansi sosial timbul karena adanya kecenderungan dari para ahli untuk mengalihkan kesejahteraan individu ke arah kesejahteraan sosial. Kecenderungan yang bergerak dari kegiatan mancari keuntungan sebesar-besarnya tanpa melihat efek samping ke arah mencari laba yang berwawasan lingkungan. Sejarah menunjukkan bahwa kelangsungan hidup manusia, kesejahteraan masyarakat 


\section{Nurhayati}

yang sebenarnya hanya dapat lahir dari sikap kerja sama antar unit-unit masyarakat itu sendiri. Perusahaan tidak akan maju tanpa dukungan dari konsumen dan lingkngan sosialnya. Kenyataan ini semakin disadari dan semakin dibutuhkan pertanggungjawabannya. Untuk mengetahui keterkaitan antara perusahaan dan lingkungan disekitarnya, mak akuntansi sosial ini sangat berperan.

Jelas di sini ditunjukkan bahwa perkembangan akuntansi tidak dapat dilepaskan dengan perkembangan dunia sosial, karena akuntansi berada dalam domain ilmu sosial, sehingga dalam menjelaskan fenomena-fenomena yang ada di dalam dunia akuntansi tentu saja harus dicari kedalaman makna dalam pengungkapan dibalik fenomena tersebut dengan paradiga interpretif. Hal ini diperkuat dengan Perlu digarisbawahi di sini bahwa manusia adalah mahluk diantara macam-macam mahkluk yang mendiami bumi yang saling mempunyai keterkaitan dan sebab akibat dan dibatasi oleh sifat keterbatasan dunia itu sendiri, baik sosial, ekonomi atau politik. Belakangan manusia semakin menyadari bahwa paradigma itu benar dan bisa dijadikan pedoman, sehingga perhatian kepada lingkungan semakin besar.

Ludigdo (2007:66-67) mengungkapkan bahwa pentingnya penelitian interpretif dalam akuntansi dalam upaya untuk memahami suatu konteks praktik professional yang bersifat kompleks, sehingga bagaimana first-hand knowledge didapatkan secara efektif dari subyek yang diinvestigasi menjadi sangat penting. Untuk itu penelitian ini perlu memperhatikan karakteristik ilmu kemanusiaan. Karena sifatnya yang demikian maka metode yang sangat mendasar dalam ilmu kemanusiaan adalah metode pemahaman (verstehen). Dengan demikian maka paradigma interpretif lebih tepat digunakan.

Giddens (2003:3) menjelakan bahwa bentuk reflektif jangkauan manusialah yang harusnya paling banyak terlibat dalam penataan rekursif praktek-praktek sosial. Kesinambungan praktek-praktek menduga adanya refleksitivitas, namun pada gilirannya refleksitivitas itu hanya mungkin terwujud bila ada kesinambungan praktek-praktek yang membuatnya jelas "sama" di sepanjang ruang dan waktu. Oleh karena itu refleksitivitas dalam interpretif harus dipahami tidak hanya 
sebagai kesadaran diri melainkan sebagai sifat arus kehidupan sosial yang sedang berlangsung yang senantiasa dimonitor. Menjadi manusia berarti menjadi manusia yang bertujuan,yang keduanya memiliki alasan-alasan atas aktivitas-aktivitasnya dan mampu, jika diminta menguraikannya secara berulang-ulang alasan-alasan itu.

Beberapa studi fenomenal yang telah dilakukan dalam bidang akuntansi menunjukkan bahwa dengan kedalaman melihat lebih jauh melalui interpretif ini membawa akuntansi menjadi lebih "manusiawi" dapat mengungkapkan apa yang terdapat di balik angka-angka akuntansi yang selama ini dipahami secara positivistik. Penelitian oleh Georgakopoulos dan Thompson (2004) mengungkapkan hasil interview yang dilakukan terhadap petani ikan salmon tentang pertimbangan apa yang mereka gunakan dalam merubah ke sistem produksi organik. Tercatat bahwa perubahan ini lebih disebabkan faktor intuisi adanya premi harga yang akan mereka terima daripada factor tekanan regulasi. Dampak akuntansi tidak terlihat dalam pengambilan keputusan perubahan metode produksi, meskipun analisis cost benefit telah dilakukan. Jelas disini bahwa interaksi akuntansi dengan lingkungan sosialnya sangat berpengaruh dalam pengambilan keputusan akuntansi.

Dalam studi interpretif seorang peneliti mempunyai keleluasaan dalam mengupas akuntansi melalui beberapa cara desain penelitian yang mungkin dapat dipilihnya, yaitu:

1. Fenomenologi

Dengan fenomenologi penelitian di bidang akuntansi dapat merefleksikan pengalaman peneliti dalam melihat relaitas sosial akuntansi, sejauh pengalaman tersebut secara intensif masih berhubungan dengan suatu obyek yang ditelitinya, Kuswarno (2009:1). Sanders (1982). Mendefinsikan fenomenologi yaitu berusaha melihat struktur yang implisit menjadi implisit dan memaknai pengalaman seseorang. Metode fenomenologi ditujukan untuk menggmbarkan elemen yang mendasar dalam fenomena untuk mengungkap esensi universal yang mendasari kesadaran manusia.

2. Etnografi

Secara harfiah berarti tulisan atau laporan tentang suatu 
suku bangsa, yang ditulis oleh seorang peneliti atas hasil penelitian lapangan (field work) selama sekian bulan, atau sekian tahun. Contoh penelitian akutansi dalam Ahrens, $\mathrm{T}$ dan Mollona, M (2007)menelusuri ketiga rangkaian studi lapangan (studi pemerintahan, teori jaringan actor/ANT, dan akuntansi dna control) terkait dengan penyelidikan konstitusi akuntansi melalui praktek organisasional dan kemunculan diskursus akuntansi, dan untuk sebagian hal kepada makna organisasional khusus melalui kajian kejadian-kejadian kunci dalam kasus sejarah di mana mereka dijadikan dasar.

Dey, Collins,. (2004) dengan menggunakan desain penelitian etnografi dapat mengungkapkan peran akuntansi sosial dalam menciptakan perdagangan yang fair (fair trade). Artikel ini menyajikan sebuah catatan riset etnografi tentang perkembangan dan implementasi sistem pencatatan akuntansi sosial yang ada di Traidcraft plc yang merupakan organisasi perdagangan di UK yang dijalankan menggunakan prinsip Kristiani.

3. Etnometodologi

Etnometodologi adalah suatu aliran sosiologi yang lahir dengan ide yang menyatakan bahwa semua manusia adalah "sosiologi praktik" Etnomeodologi tidak terpisah dari kelompok penelitian ilmu-ilmu sosial. Bahkan ia bertalian dengan aliran-aliran, seperti marxisme, fenomenologi, eksistensialisme dan interaksionisme, yang memperkaya pemikiran mutakhir tentang masyarakat (Coulon,vii).Di Indonesia, salah satu penelitian akuntansi yang secara eksplisit menggunakan pendekan etnometodologi adalah penelitian Ludigdo (2006). Penelitiannya mengguna-kan setting institusi kantor akuntan publik dalam bidang kajian praktik etika.

4. Narasi

Peneliti boleh menggunakan alasan paradigmatik untuk kajian naratif, seperti bagaimana individu dimampukan dan dipaksa oleh sumberdaya sosial, disituasikan secara interaktif, dan bagaimanapencerita membangun interpretasinya.

\section{Grounded theory}


Penelitian Grounded Theory adalah metode penelitian kualitatif yang menggunakan sejumlah prosedur sstematis yang diarahkan unutk mengembangkan teori berorientasi tindakan, interkasi, atau proses denganberlandaskan data yang diperoleh dari kancah penelitian. Metode penelitian ini masih tergolong baru dan belum banyak digunakan dalam riset-riset akuntansi.

Untuk memperjelas bagaimana desain penelitian apa yang digunakan dan apakah alat analisis yang tepat untuk digunakan, maka di bawah ini Triyuwono (2013) menyajikan berbagai desain penelitian interpretif dalam sebuah tabel.

Tabel 2

Tujuan dan Bentuk Ilmu dari Masing-masing Paradigma

\begin{tabular}{|c|c|c|c|}
\hline No & Paradigma & Desain penelitian & Alat analisis \\
\hline 1 & Positivis & Studi kasus & $\begin{array}{l}\text { Teori atau konsep } \\
\text { akuntansi }\end{array}$ \\
\hline 2 & interpretivis & $\begin{array}{l}\text { Fenomenologi, } \\
\text { etnografi, } \\
\text { etnometodologi, } \\
\text { narasi, studi kasus, } \\
\text { grounded theory }\end{array}$ & $\begin{array}{l}\text { Teori fenomenologi, } \\
\text { teori etnografi, teori } \\
\text { hermeneutika,dan } \\
\text { lain-lainnya }\end{array}$ \\
\hline 3 & kritis, & $\begin{array}{l}\text { Studi kasus, kritis, } \\
\text { aksi, feminis, } \\
\text { etnografi kritis }\end{array}$ & $\begin{array}{l}\text { Teori-teori kritis, } \\
\text { misalnya teori } \\
\text { komunikasi aksi } \\
\text { Habermas, } \\
\text { psikoanalisis, teori } \\
\text { marxis, } \\
\text { hermeneutika kritis, } \\
\text { ekonomi politik, dan } \\
\text { lain-lainnya }\end{array}$ \\
\hline 4 & postmodernis & $\begin{array}{l}\text { Studi kasus, } \\
\text { feminis, } \\
\text { narasi, diskursus }\end{array}$ & $\begin{array}{l}\text { Kombinasi dari } \\
\text { berbagai teori dari } \\
\text { wilayah interpretivis } \\
\text { dan kritis dengan } \\
\text { budaya, agama, dan } \\
\text { lain-lainnya } \\
\end{array}$ \\
\hline 5 & spiritualis & "Suka-suka saya" & Intuisi \\
\hline
\end{tabular}

Sumber: Triyuwono (2013) 
Pandangan interpretif terhadap akuntansi berfokus pada penjelasan susunan sosial dari sudut pandang normalisme, antipositivisme, voluntarisme, dan ideologika. Pada akuntansi, pandangan ini bertujuan untuk memahami pengalaman subjektif individual yang terlibat dalam penyiapan, pengkomunikasian, pembuktian, atau penggunaan informasi akuntansi. Penerapan hermeneutics dalam akuntansi berfokus pada bidang objektifikasi (pengungkapan secara objektif) akuntansi, seperti lembagalembaga akuntansi, teks akuntansi, literatur akuntansi, bahasabahasa akuntansi, dan ideologi akuntansi. Walaupun pada masa permulaan, paradigma interpretif pada akuntansi telah berfokus pada:

1. kemampuan informasi akuntansi untuk "menyusun realitas",

2. peran akuntansi sebagai "alat linguistik (berkenaan dengan ilmu bahasa" dan

3. peran dan citra lain yang dapat disandang oleh akuntansi. Sehingga asumsi yang dominan pada pandangan interpretif terhadap akuntansi adalah:

1. Keyakinan mengenai pengetahuanpenjelasan ilmiah mengenai pencarian tujuan manusia. Kesesuaiannya ditetapkan melalui kriteria konsistensi logika, interpretasi subjektif, dan persetujuan dengan interpretasi pengetahuan umum yang dimiliki oleh pihak yang melakukan tidakan.

2. Keyakinan mengenai realitas fisik dan sosial Realitas sosial merupakan sesuatu yang muncul, dihasilkan secara subjektif, dan diungkapkan secara objektif melalui interaksi antar manusia.

\section{Simpulan}

Walaupun banyak akuntan yang tidak berpengalaman dalam bidang akuntansi atau bahkan dalam bidang manajemen, tidak memengaruhi kapasitas akuntansi sebagai kumpulan praktik, dan makna institusi akuntansi yang lebih luas, yang membentuk idiologi.

Akuntan bertanggungjawab untuk membentuk idiologi meskipun mayoritas akuntan hanya mengacu pada pelaksanaan 
praktik akuntansi itu sendiri (Roslander, 1992:88-89).Melalui penelitian kualitatif pada umumnya, dan paradigma interpretif pada khususnya akan memberikan sumbangan konstruksi idiologi dalam akuntansi karena interpretif dimulai dari suatu fenomena yang selanjutnya didalami untuk menghasilkan teori.

Penelitian interpretif mempunyai 6 desain penelitian, diantaranya: fenomenologi, etnografi, etnometodologi, narasi, studi kasus, dan grounded theory. Penelitian interpretif berbeda dengan penelitian positivistik, dimana dalam penelitian interpretif dapat menggunakan salah satu atau lebih desain penelitian dalam satu riset yang sama. 


\section{DAFTAR PUSTAKA}

Ahrens, T dan Mollona, M (2007) Organisational Control As Cultural Practice - A Shop Floor Ethnography Of A Sheffield Steel Mill

Alvesson, M. dan K. Skoldberg. 2000. Reflexive Methodology. Sage Publication. London,

Basrowi, M dan Soenyono, 2004. Teori Sosial dalam Tiga Paradigma, Yayasan kampusina Surabaya.

Burrel, G and Morgan G. 1979. Sociological Paradigms and organizational Analysis : Elements of the Sociology of Corporate Life. London: Heinemann

Behling, Orlando, 1980.The Case For The Natural Science Model For Research In Organizational Behavior And Organization, Academy of Management. The Academy of Management Review (pre-1986); Oct 1980; 5, 000004; ProQuest pg. 483

Coulon, Alain, 2008. Etnometodologi, Lengge, Yogyakarta.

Churchill Jr, Christian J., (2005), Ethnography as a translation, Qualitative Sociology, Vol. 28. No. 1. Spring.

Dahlan., Moh. 2009. Relasi Sains Modern dan Sains Islam Suatu Upaya Pencarian Paradigma Baru. Volume 12 No. 2

Denzin, N.K. 1989. Interpretive Interactionism.Applied Sosial Research Methods Series Vol. 16. Sage Publications, California.

Denzin, N.K. dan Lincoln, Y.S.2009. Handbook of Qualitatif Research.Pustaka Pelajar, Yogyakarta.

Dey, Collins,. (2004), Social Accounting at Traidcraft PLC: An 
Ethnographic Study of A Struggle for The Meaning of Fair Trade.

Farnetti, Frederica., and Guthrie, James., (2009) Sustainnability Reporting by Australian Public Sector Oreganization : Why They Report? Accounting Forum 33, pp. 89-98.

Georgakopoulos, G and Thompson, I, (2004), Organic Salmon Farming : Risk Perception, Decision, Heuristic and the Absence of Environmental Accounting, Fourth Asia Pacific Interdisciplinary Research in Accounting Conference, 4 to 6 July 2004, Singapore.

Giddens,A. 2003. The Constitution of Society; TeoriStrukturasi UntukAnalisisSosial. Penerbit Pedati, Pasuruan. Diterjemahkandarijudulasli "The Constitution of Society: The Outline of the Theory of Structuration", Polity Press Cambridge - UK, 1995.

Guthrie, James., Cuganesan, Suresh., and Ward, Leanne,. (2008). Industry Specific Social and Environmental Reporting : The Australian Food and Beverage Industry, Accounting Forum 32, pp 1-15

Kristiyanto,Eddy. 2004.ReformasidariDalam.Kanisius,Yogyakarta

Kuswarno, Engkus, 2009. Fenomenologi, Konsepsi, Pedoman, dan Contoh Penelitian, Penerbit Widya Padjadjaran, Bandung.

Ludigdo, 2006.Pemahaman Strukturasi Atas Praktik Etika di Sebuah Kantor Akuntan Publik, Disertasi, tidak dipublikasikan, Universitas Brawijaya Malang

Ludigdo, 2007. Paradoks Etika Akuntan, Pustaka Pelajar, Yogyakarta

Neuman, W.L. 2000. Social Research Methods; Qualitative and Quantitative Approach. A Pearson Eduacation 
Nurhayati

Company, USA.

O'Collins, Gerald dan G. Farrugia, Edward. 1996. Kamus Teologi, Entri “Nominalisme” Kanisius, Yogyakarta.

Raar, Jean.. (2004), Environmental and Social Responsibility: A Normative Financial reporting Concept, Accepted for Presentation at the Fourth Asia Pacific Interdisiplinary research in Accounting Conference, 4-6 July 2004 in Singapore.

Roslender, Robin, 1992. Sociological Perspectives on Modern Accountancy, Routledge, London

Sanders, Patricia (1982). Phenomenology A New Way of Viewing Oragnizational Research, Academy management Review, Vo. 7, No. 3. pp. 353-360

Solomon, Jill Frances and Thomson, Ian (2009). Satanic Mills : An Illustration of Victorian External Environtmental Accounting, Accounting Forum 33, pp. 74-87

Spradley, J.P. 1997. Metode Etnografi. Penerbit PT Tiara Wacana, Yogyakarta. Diterjemahkan dari judul asli The Ethnographic Interview.

Suriasumantri, J. S. 1993. Filsafat Ilmu Sebuah Pengantar Populer: Jakarta

Knuuttila,MLK, et al, 2008. Straddling Between Paradigms: A Naturalistic Philosophical Case Study On Interpretive Research In Management Accounting. Accounting Orgaiztionations, and Society, Vol 33 (2008) 267-291

Triyuwono, Iwan. 2007. Mengangkat "Sing Liyan" untuk Formulasi Nilai Tambah Syariah. Jurnal Akuntansi Multiparadigma. (Volume 1, Nomor 1, April 2010, 161162). 
Melukiskan Akuntansi dengan Kuas Interpretif

Triyuwono, Iwan , 2013. Makrifat Metode Penelitian Kualitatif Dan Kuantitatif Untuk Pengembangan Disiplin Akuntansi, Makalah ini diseminarkan dalam acara Simposium Nasional Akuntansi ke-16 di Manado pada tanggal 25-27 September 2013. 
BISNIS, Vol. 3, No. 1, Juni 2015 